\title{
"LÁGRIMAS FRACAS, DORES MÍNIMAS, CHUVAS OUTONAIS": A POÉTICA DA MELANCOLIA EM TRÊS ESCRITORAS LUSÓFONAS
}

\section{"WEAK TEARS, MINIMUM PAIN, AUTUMN RAINS": THE POETRY OF MELANCHOLY IN THREE LUSOPHONE WRITERS}

STACUL, Juan Filipe ${ }^{1}$

RESUMO: No presente trabalho, pretende-se realizar uma investigação acerca das relações entre melancolia, enunciação e literatura, especificamente, em três grandes nomes da poesia contemporânea em língua portuguesa: Noémia de Sousa (Moçambique), Florbela Espanca (Portugal) e Ana Cristina Cesar (Brasil). Para tanto, foram selecionados textos em que se verifica a recorrência da dicção melancólica como traço constituinte da lírica de cada uma das poetisas. Pretende-se, com tal análise, verificar que a constituição de uma poética da melancolia nessas autoras, resguardados os devidos panoramas histórico-culturais, instaura-se no limiar entre os questionamentos existenciais do indivíduo e a crítica aos modelos institucionais e às questões políticas e sociais vigentes, estabelecendo um processo que reverbera uma melancolia coletiva na voz do eu-lírico.

PALAVRAS-CHAVE: Melancolia, Poesia, Florbela Espanca, Noémia de Sousa, Ana Cristina Cesar, Enunciação, Literatura Comparada.

\begin{abstract}
In this work, we intend to conduct an investigation on the relationship between enunciation, melancholy and literature, specifically in three great names of contemporary poetry in Portuguese: Noémia de Sousa (Mozambique), Florbela Espanca (Portugal) and Ana Cristina Cesar (Brazil). To this analysis, we selected texts where there is a recurrence of the melancholy as a trace constituent of lyricism. We intended verify that the establishment of a poetic melancholy of these authors, guarded proper historical and cultural panoramas, is established at the threshold between the existential questions of individual and the institutional forces, establishing a process that reverberates a collective melancholy in the lyrical voice.
\end{abstract}

\footnotetext{
${ }^{1}$ Professor do Instituto Federal de Goiás (IFG). Doutor em Literaturas de Língua Portuguesa pela PUC Minas, com estágio pós-doutoral na Universidade Federal de Viçosa-UFV. E-mail: juan.stacul @ifg.edu.br 
KEYWORDS: Melancholy, Poetry, Florbela Espanca, Noémia de Sousa, Ana Cristina Cesar, Enunciation, Comparative Literature.

\section{INTRODUÇÃO}

Poesia e melancolia: uma das combinações mais recorrentes na historiografia literária. Desde a saudade melancólica das cantigas trovadorescas, até o byronismo oitocentista, perpassando o saudosismo modernista e o pessimismo niilista dos marginais, a dicção melancólica é o traço constituinte de boa parte de nossa produção lírica. Da mesma forma, parece-nos muito presente no senso comum a associação entre poesia e tristeza, saudade, lamentação, ausência e solidão.

Instigados por essas relações e tendo em vista as distintas configurações entre poesia e melancolia evidenciadas no contexto contemporâneo, resolvemos investigar como seria possível localizar e caracterizar o que chamamos de dicção melancólica na lírica de três grandes poetisas da literatura em língua portuguesa: Florbela Espanca, Noémia de Sousa e Ana Cristina Cesar.

Florbela Espanca foi uma das mais representativas poetisas portuguesas. Viveu pouco, mas produziu uma obra densa, de alto valor estético e de singular composição estilística. Sua poesia, produzida nas primeiras décadas do século $\mathrm{XX}$, versam sobre a solidão, o desespero e a melancolia. A autora, como poucas, sobre representar de forma paradigmática as agruras do sujeito moderno, apagado pela frieza de um universo urbano em ascensão e marcadamente depressivo.

Para o estudo que ora propomos, selecionamos a poesia "Este livro...", que é uma espécie de preâmbulo do Livro de Mágoas (1919), no qual o eu-lírico convoca os desgraçados e desafortunados leitores para a leitura da obra. Nesse caso, pretendemos verificar como a autora estabelece uma espécie de pacto ficcional às avessas, pelo meio do que denominamos de mascaramento desmascarado da instância autoral.

Em interlocução com o texto de Espanca, selecionamos o poema-carta "Carta de Paris", de Ana Cristina Cesar, escritora brasileira, nome importante da geração mimeógrafo - um dos primeiros grupos a instaurarem a estética marginal na literatura brasileira, na década de 1970. Subversiva, tanto na forma quanto no conteúdo, a poesia de Cesar propõe um imbricamento entre os gêneros (literários e discursivos) e uma reconfiguração da relação entre o eu e o outro, por meio de um "fingimento" fático e 
metalinguístico, que traz para o texto poético um contexto comunicativo que "simula o real".

Nesse sentido, pretendemos analisar a obra de Cesar sob o prisma da teoria da enunciação, conforme as discussões de Benveniste (1991). Defendemos, nesse caso, que assim como Espanca convoca o leitor para um possível diálogo, Cesar simula uma interação com seus leitores, mesclando a linguagem poética com a das cartas e estabelecendo uma espécie de jogo teatral que perscruta uma aproximação entre o leitor e a obra.

De forma semelhante, mas com uma intencionalidade social e política bem mais intensa, insere-se a obra de Noémia de Sousa, moçambicana, poetisa e ativista vinculada aos movimentos pela independência de Moçambique. Em sua criação literária, Noémia procurou trazer à tona a voz do povo africano, em diálogo com outros movimentos estéticos e culturais pelos direitos da população negra.

Para a nossa análise, selecionamos o poema "Deixa o meu povo passar...", parte da coletânea Sangue Negro (2001), em que o eu-lírico, a partir de uma relação intertextual com a música gospel norte-americana Go Down Moses, de Louis Armstrong, e com a passagem bíblica da libertação do povo judaico, lança um brado de apoio à libertação do seu povo e discorre sobre a agonia e o desespero pelo caráter cativo em que se encontram.

No texto de Noémia, vislumbramos uma espécie de "melancolia social", ou seja, a reverberação de um sentimento melancólico pretensamente coletivo na voz do eu-lírico, que embora perpasse tanto a poesia de Espanca quanto a de Ana Cristina Cesar, intensifica-se de forma considerável na proposta estética e política de Noémia de Sousa.

A partir desse corpus que procuramos apresentar no breve panorama supracitado, objetiva-se, no presente trabalho, entender as implicações da dicção melancólica para a criação literária nesses três contextos especificamente delimitados: o Moçambique de Noémia Sousa, o Portugal de Florbela Espanca e o Brasil de Ana Cristina Cesar - ou se focarmos ainda mais a nossa lente, as relações entre o $e u$ (individual) e o $t u$ (coletivo) enquanto instâncias líricas na obra dessas três artistas.

Nesse sentido, o presente trabalho procura relacionar a temática da melancolia e da solidão, tão presente nas poesias aqui citadas, ao processo de embate dos sujeitos enunciativos, vistos aqui como parte paradoxal de um processo de subjetivação e de levante contra os mecanismos repressivos, marcadamente presentes na vida e na obra dessas três poetisas, cada uma em seu momento e com suas singularidades. 


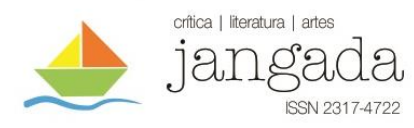

O presente trabalho se justifica, portanto - apesar da já reconhecida fortuna crítica acerca dos nomes aqui citados e, sobretudo, da temática em questão - pela tentativa de possibilitar novos olhares críticos sobre as relações entre sujeito e alteridade, sobretudo quando as barreiras que tradicionalmente pareciam distanciar o prisma de tais relações se tornam cada vez mais fluidas. Nesse sentido, acreditamos que uma análise comparativa entre a obra de Noémia de Sousa, Ana Cristina Cesar e Florbela Espanca pode acrescentar discussões bastante pertinentes a tais problemáticas.

Nossa hipótese, a esse respeito, é a de que as três autoras colocam em evidência as cenas enunciativas, conforme definidas por Benveniste (1991), no cerne do texto poético. No entanto, cada autora destaca uma particularidade do processo de enunciação, de acordo com uma proposta estética e política: 1) Florbela Espanca evidencia as nuances do pacto autobiográfico e da relação entre autor e leitor; 2) Noémia de Sousa questiona o papel do ele/outro no momento da enunciação e 3) Ana Cristina Cesar relativiza fronteiras textuais e contextuais. A dicção melancólica, nesse ínterim, surge como um denominador comum no trato com a composição literária.

\section{POR UMA ESTÉTICA DA MELANCOLIA}

Sabe-se que o conceito de melancolia, assim como a sua figuração na literatura, pode assumir várias configurações. Nesse sentido, é importante distinguirmos algumas questões operacionais, com o objetivo de vislumbrarmos a temática de forma mais panorâmica e localizarmos, com isso, uma noção que abarque com propriedade as discussões que pretendemos realizar acerca da obra de Florbela Espanca, Noémia de Sousa e Ana Cristina Cesar.

Primeiramente, é importante que façamos uma distinção conceitual sobre o tipo de melancolia que pretendemos analisar na obra poética dessas três autoras, pois esse esclarecimento nos ajudará a vislumbrarmos a dicção melancólica como um traço estético de feições próprias. Com isso, propomos o estudo da melancolia como um aspecto subjetivo inerente à construção do eu-lírico e não como uma condição psicológica característica das escritoras e reverberada em sua escrita.

A esse respeito, são bastante pertinentes as considerações que Julia Kristeva tece sobre a melancolia, em sua obra Sol Negro - Depressão e Melancolia (1989): 


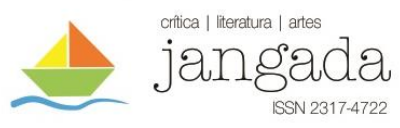

Conscientes de estarmos destinados a perder nossos amores, ficamos talvez ainda mais enlutados ao perceber no amante a sombra de um objeto amado, outrora perdido. A depressão é o rosto escondido de Narciso. (...) Desta vez, entretanto, não veremos ali a esplendorosa e frágil idealização amorosa, mas, pelo contrário, a sombra lançada sobre o ego frágil, mal dissociado do outro, precisamente pela perda desse outro necessário. Sombra do desespero. (KRISTEVA, 1989, p. 13)

O conceito de melancolia apresentado por Kristeva nos é caro por articular-se com duas noções que pretendemos investigar no trabalho em questão: sua relação com o erotismo e com o indissociável imbricamento entre o eu e os outros (tu e ele). Dessa forma, salienta-se que tanto o conceito de depressão quanto o de melancolia, em Kristeva, relacionam-se com a questão da intersubjetividade, ou seja, com a forma como os indivíduos se relacionam na prática cotidiana, sob o crivo do olhar de si sobre seus pares e, consequentemente, dos outros sobre si mesmo.

Assim, a melancolia emerge, analogamente ao pensamento freudiano, como uma ausência, um desconforto causado pela compreensão da perda do objeto amado. Na psicanálise, esse processo desencadearia um estágio clínico compreendido, segundo Kristeva, como "a sintomatologia psiquiátrica de inibição e de assimbolia que, por momentos ou de forma crônica, se instala num indivíduo" (KRISTEVA, 1989, p. 16).

Mas como, afinal, essa noção clínica da melancolia poderia nos iluminar para a compreensão de uma estética melancólica nas artes? Sem queremos nos aprofundar no pensamento médico sobre a questão, gostaríamos de trazer à tona, no entanto, uma conclusão à qual chega a própria Kristeva - que, de certa forma, serve como uma espécie de ponto de partida para que possamos pensar na melancolia em seu caráter estético:

A Coisa melancólica interrompe a metonímia desejante, assim como ela se opõe à elaboração intrapsíquica da perda. Como se aproximar desse lugar? A sublimação faz uma tentativa neste sentido: por melodias, ritmos, polivalências semânticas, a forma dita poética, que decompõe, refaz os signos, é o único "continente" que parece assegurar um domínio incerto, mas adequado, sobre a Coisa. (KRISTEVA, 1989, p. 20) 


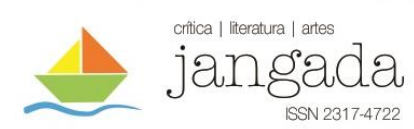

Partimos, portanto, de uma compreensão da melancolia como ausência e inarticulação para visualizarmos as artes, especificamente, em nosso caso, a literatura, como o local em que se tornaria possível recuperar o “objeto" perdido, reestabelecer certa ordem sobre o caos gerado pela assimbolia do estágio melancólico.

Em sintonia com esse pensamento, Goulart (2012), afirma que "A literatura se enquadra no rol de mecanismos com que lida o ser humano, no sentido de encontrar respostas para incontáveis dúvidas que o atormentam" (GOULART, 2012, p. 3). Para o autor, a ciência, os mitos, os credos religiosos e a arte seriam os quatro mecanismos encontrados pelo homem para lidar com as ausências e angústias e, nesse sentido, “organizar o caos" e "aliviar suas tensões". (GOULART, 2012, pp. 3-4)

Se é possível, portanto, localizarmos a literatura nesse lugar de realocação da ausência, cabe ao crítico literário localizar em que grau isso ocorre e de que forma podemos visualizar esse processo na escrita de determinados autores. Dessa forma, defendemos a constituição de uma estética melancólica ou poética da melancolia como algo que se torna evidente no texto por meio de mecanismos estilísticos, mas transcendendo-o para as relações extrínsecas à obra e inerentes ao sistema literário, ou seja, aos momentos de produção e recepção do material artístico.

Nesse sentido, nas próximas páginas pretendemos perscrutar os mecanismos utilizados pelas três autoras, na tentativa de localizarmos uma síntese constituinte de uma estética melancólica. Tentaremos, nesse trajeto, distanciarmo-nos de uma leitura psiquiátrica de melancolia e, consequentemente, de possíveis - e problemáticas conjecturas sobre traços melancólicos e depressivos na figura autoral, para focarmos nossa lente nos mecanismos intrínsecos ao texto, que apontam para a constituição de uma "dicção" melancólica, assim como seus imbricamentos para a cena enunciativa evidenciada nas poesias em análise.

\section{MASCARAMENTOS DESMASCARADOS: SUBVERTENDO O PACTO AUTOBIOGRÁFICO}

"Este livro é de mágoas. Desgraçados/ Que no mundo passais, chorai ao lê-lo!/ Somente a vossa dor de Torturados/ Pode, talvez, senti-lo... e compreendê-lo...": com esses versos, Florbela Espanca, no poema "Este livro...", convoca seus desventurados e 
depressivos leitores a comungarem das angústias e sofrimentos que, a partir daquele momento, mostrar-se-ão nas páginas do Livro de Mágoas (1919), em forma de poesia.

O poema, espécie de prólogo ou nota introdutória, estabelece de imediato uma ligação pactual com o leitor, pois, desde o primeiro momento, deixa claro a quem se destinam aqueles poemas e de que forma esse receptor deverá lidar com as mensagens que ali se encontram. Nesse sentido, "desgraçados" e "torturados" não são meras adjetivações, mas vocativos a um possível interlocutor que deverá se identificar com os poemas de forma catártica, pois, como sugere o eu-lírico, pertencem ao seu mesmo universo ou grupo.

A poesia de Espanca, nesse momento, apresenta traços muito sutis daquilo que Lejeune, em seus estudos voltados para o texto em prosa, especificamente, das autobiografias, denomina de pacto autobiográfico: "Para que haja autobiografia (e, numa perspectiva mais geral, literatura íntima) é preciso que haja relação de identidade entre o autor, o narrador e o personagem". (LEJEUNE, 2008, p. 15)

Nesse momento, questionar-se-ia a ausência de qualquer vestígio na poesia de Espanca, sobretudo no trecho em questão, em que se tornasse evidente qualquer informação que atrelasse de forma direta a identidade da autora com a do eu-lírico e que, de algum modo, reverberasse alguma forma pactual para com o leitor. Há que se observar, no entanto, que há sim um pacto de identificação entre o eu lírico e a pessoa autoral e, da mesma forma, uma tentativa de evidenciação de um contexto enunciativo. Para embasar tal afirmativa, centramo-nos em dois movimentos seguidos no trecho em questão: o uso dos dêiticos e o processo metonímico.

Primeiramente, destacamos que "Este" e "Vossa" estabelecem, antes de mais nada, uma relação exofórica no trecho em questão - ou seja, conectam não apenas a estrutura sintática dos primeiros versos, mas também as relações contextuais e discursivas que lhe são inerentes. Com esses elementos, denominados de dêiticos pela gramática normativa, estabelece-se um contato direto com um contexto comunicativo em que "este" refere-se a um objeto concreto próximo ao locutor (livro) e "vossa" refere-se a um sentimento do alocutário (dor). Em ambos os casos, vislumbramos uma tentativa de "concretizar" o leitor virtual, aproximando-o da obra e do autor. Da mesma forma, esses elementos sugerem uma espécie de pacto autobiográfico ao sussurrarem ao possível leitor do livro: você e eu estamos aqui, juntos, no mesmo momento comunicativo. Conhecemonos e dialogamos um com outro. 
Paradoxalmente, um outro elemento presente no texto mascara novamente o autor desnudado: o "livro" como metonímia da voz autoral. Nesse caso, quando transfere sua subjetividade, sentimentos e sensações para a figura do livro, o eu-lírico se distancia do contexto comunicativo e, de certa forma, isola-se do contato "físico" pretensamente estabelecido com o seu leitor. Nos versos seguintes, esse processo torna-se ainda mais intenso:

Este livro é para vós. Abençoados

Os que o sentirem, sem ser bom nem belo!!

Bíblia de tristes... Ó Desventurados,

Que a vossa imensa dor se acalme ao vê-lo!

(ESPANCA, 2014)

Observa-se, nesse caso, como a voz autoral se distancia cada vez mais de seu leitor virtual, assim como a presença do próprio eu-lírico, a partir de uma atribuição de completa autonomia e personificação do "livro". Por outro lado, o mesmo leitor virtual torna-se cada vez mais parte desse contexto, sempre evidenciado pelos dêiticos "vós", "o", "vossa" e pelos adjetivos e/ou vocativos "Abençoados", "Desventurados". Além disso, torna-se claro o grau de conhecimento da intimidade do leitor por parte da instância autoral, que não se limita em julgá-lo: “Os que o sentirem”, "Vossa imensa dor".

Importante mencionar, inclusive, o termo "Bíblia de tristes" como bastante paradigmático para as discussões que vínhamos suscitando anteriormente sobre os mecanismos utilizados pelo sujeito para organização do caos gerado pela ausência melancólica. Nesse sentido, o próprio eu-lírico visualiza a potência quase religiosa de sua obra, como forma de expressão de um sujeito melancólico para um outro também melancólico, estabelecendo, novamente, uma relação pactual.

Podemos perceber que todos esses elementos anteriormente apresentados podem ser visualizados como mecanismos estilísticos que evidenciam os traços melancólicos da escrita de Espanca e atuam no papel de constituintes de uma estética melancólica, embasada, nesse caso, por meio de um processo de aproximação e de afastamento. A esse respeito, inclusive, os últimos versos são muito sintomáticos, pois reverberam uma retomada da presença da instância autoral, que, então, confunde-se com o livro:

Livro de Mágoas... Dores... Ansiedade 
Livro de Sombras... Névoas... e Saudades!

Vai pelo mundo... (Trouxe-o no meu seio...)

Irmãos na Dor, os olhos rasos de água,

Chorai comigo a minha imensa mágoa,

Lendo o meu livro só de mágoas cheio!...

(ESPANCA, 2014)

Além de elementos que desempenham papeis já discutidos anteriormente, como a metonímia e o uso dos dêiticos, destaca-se, nesse excerto, a presença das frases "trouxeo no meu seio" e "lendo o meu livro". Ambas, no contexto em que se apresentam, promovem uma reaproximação do eu-lírico e realocam o sujeito autoral no interior da escrita poética. Afinal, quem carrega o livro "no seio" não é a instância textual, mas a escritora e, enfaticamente, a mulher que concebe a escrita como um filho. Da mesma forma, "meu livro" refere-se, deiticamente, à poetisa.

Observamos, a partir de tais considerações, que a escrita de "Este poema..." constrói-se a partir de uma série de recursos que colocam em xeque as relações entre produção e recepção textual, (auto)ficcionalidade e alteridade para, a partir disso, estabelecer-se enquanto uma produção literária que coloca a dicção melancólica como jogo entre o eu e o $t u$, o autor e o leitor. Nesse sentido, entender a melancolia em Florbela Espanca pressupõe, também, entender um mal-estar social com a qual a autora dialoga. Nesse caso, uma relação de conforto para os desafortunados, os depressivos, os que sofrem na vida.

Com feições distintas, a poética de Noémia de Sousa também coloca alguns desses questionamentos em questão. Enfatiza-se, no caso desta autora, a preponderância de um eu social específico, politicamente marcado; ao contrário da escrita de Florbela, em que se contemplam os desafortunados de uma forma geral (mas que parecem fazer referência aos depressivos e melancólicos de uma modernidade em ascensão). A seguir, discutiremos com maior propriedade como podemos vislumbrar os processos de construção poética que situam Noémia de Sousa do patamar de uma estética melancólica, com traços singulares, mas que dialogam, de alguma forma, com o processo de construção da poesia de Florbela Espanca. 


\title{
3. O EU E OS OUTROS: UM MAL-ESTAR SOCIAL
}

Para compararmos a poética de Noémia de Sousa, em "Deixa passar o meu povo", com o processo de composição de Florbela Espanca, basta observarmos que em ambas as autoras ocorre, desde o início de suas poesias, uma identificação que traz a instância autoral para dentro da criação artística. No caso de Noémia, esse processo se dá de forma ainda mais intensa, pois a autora deixa transparecer a todo instante uma série de indexadores textuais que remetem a sua vida pessoal, além das palavras.

No poema em questão, Noémia apresenta inicialmente a ambientação moçambicana, depois características de sua residência, e, por fim, referências a personalidades musicais que admira e cuja produção, inclusive, será evidenciada intertextualmente ao logo da poesia. Para que possamos visualizar com clareza alguns desses elementos, a seguir, apresentamos as duas primeiras estrofes do poema:

\author{
Noite morna de Moçambique \\ e sons longínquos de marimbas chegam até mim \\ -- certos e constantes -- \\ vindos nem eu sei donde. \\ Em minha casa de madeira e zinco, \\ abro o rádio e deixo-me embalar... \\ Mas as vozes da América remexem-me a alma e os nervos. \\ E Robeson e Maria cantam para mim \\ spirituals negros do Harlem. \\ Let my people go \\ -- oh deixa passar o meu povo, \\ deixa passar o meu povo --, \\ dizem. \\ E eu abro os olhos e já não posso dormir. \\ Dentro de mim soam-me Anderson e Paul \\ e não são doces vozes de embalo. \\ Let my people go.
}

Nervosamente, 
sento-me à mesa e escrevo...

(Dentro de mim,

oh let my people go...)

deixa passar o meu povo.

(SOUSA, 2001, p. 57)

Primeiramente, ressalta-se o uso de dêiticos para retomada de informações externas ao texto e, com isso, estabelecer um canal de comunicação que configure um diálogo. Dessa forma, assim como vimos na poesia de Florbela Espanca, elementos textuais como "eu", "mim" e "meu", tentam aproximar as duas instâncias (con)textuais autor e leitor - e promover, desde o início, uma espécie de pacto autobiográfico, ou, nesse caso, pacto metaficcional.

Além da presença dos dêiticos, Noémia traz para sua escrita uma espécie de função referencial, por meio da inclusão de elementos cotidianos da vida da escritora, que atribuem ao texto um ar documental e autoficcional. Esse tipo de recurso torna-se bastante evidente em trechos como "minha casa de madeira e zinco", "eu abro os olhos e já não posso dormir", "abro o rádio e deixo-me embalar", que situam o leitor no universo pessoal da escritora. Esse artifício se intensifica na segunda estrofe, quando a descrição do processo criativo, evidenciada em "Nervosamente,/sento-me à mesa e escrevo...", traz o leitor para o cerne da produção artística.

Esse trabalho com a linguagem poética que vislumbramos, inicialmente, em Florbela Espanca e, agora, em Noémia de Sousa, coloca-nos diante de uma noção do texto literário como enunciado, produzido dentro de um cenário enunciativo específico e tendo como princípio o estabelecimento de um diálogo efetivo. Além e aquém da função poética, vislumbramos, portanto, um eu e um $t u$ que compartilham um texto politicamente marcado - processo este que se vincula, muito provavelmente, ao ativismo da autora nos movimentos pelos interesses do povo moçambicano.

Sobre tais aspectos, somam-se como de especial relevância as noções de sujeitos da enunciação, conforme apresentadas por Benveniste (1991). De forma bastante sintética, podemos caracterizar as teorizações de Benveniste da seguinte forma: a cada pessoa gramatical, atribuiríamos uma instância enunciativa. Dessa forma, essas pessoas correlacionam-se de forma intersubjetiva, evidenciado três processos: um eu que fala com alguém (tu) sobre alguém (ele). Nesse processo, conforme se torna evidente no quadro 
acima apresentado, o ele, pessoa de quem se fala, ocupará um lugar de objeto, de "nãopessoa" 2

Ressalta-se, das teorizações de Benveniste, uma noção que é bastante cara à análise que aqui propomos sobre a poesia de Noémia de Sousa: “É na linguagem e pela linguagem que o homem se constitui como sujeito; porque só a linguagem fundamenta na realidade, na sua realidade que é a do ser, o conceito de ego". (BENVENISTE, 1991, p. 288)

Nesse ínterim, visualizamos a proposta de Noémia de se estabelecer como sujeito pela linguagem, nesse caso, poética. Esse estabelecer-se como sujeito, no entanto, não diz respeito a uma mera configuração da subjetividade pela produção textual, mas um constituir-se como sujeito múltiplo, dialógico, que coloca em sua produção textual múltiplas concepções de um eu individual (poeta, escritora, ativista, mulher, negra) que reverbera em um eu coletivo (negros, africanos, mulheres) e que, com isso, traz à tona uma proposta política que transborda pelas linhas de sua poesia.

Nesse tom crítico é que a dicção melancólica presente na poesia vai se constituir como um clamor pelo eu coletivo que sofre e que clama por liberdade. Dessa forma, Noémia traz o brado de "Let my people go" como uma forma de demarcar sua posição enquanto sujeito que se coloca no lugar do outro e que grita pela liberdade de seu povo. Nesse caso, a autora estabelece um $e u$ autoficcional, que fala com um $t u$ leitor, sobre um ele povo. Percebe-se que, ao contrário do que era evidente na poesia de Florbela Espanca, o leitor não desempenha o mesmo papel de tu coletivo conclamado pelo $\mathrm{eu}$ individual, que comungava de suas atribulações. O leitor de Noémia é outra pessoa, que precisa desesperadamente ouvir e entender o grito de "deixa passar o meu povo". A massa melancólica, os desgraçados e desafortunados, portanto, não são aqueles que encontram no livro, ou no poema, um bálsamo para suas aflições, mas aqueles que estão à margem, objetificados pela terceira pessoa, precisando do grito da escritora para serem reconhecidos como sujeitos.

Interessante notar, a esse respeito, que a poesia de Noémia, assim como a de Florbela Espanca, vai se constituir por meio de um processo de afastamento e de aproximação. Se, por um lado, o eu-lírico coloca o povo moçambicano como terceira pessoa do discurso e lança um grito distante de libertação de seus pares; por outro, não

\footnotetext{
${ }^{2}$ Cf. BENVENISTE, 1991.

${ }^{3}$ Referência intertextual ao clássico gospel norte-americano "Go Down Moses", de Louis Armstrong; em que se rememora a libertação do povo judaico, no Antigo Testamento.
} 


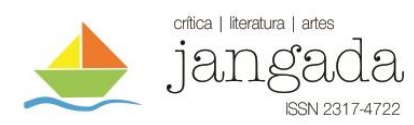

vai conseguir permanecer no lugar ao qual se engendrara, imbricando-se com esse eu coletivo e evidenciando seu pertencimento neste grupo:

\author{
E já não sou mais que instrumento \\ do meu sangue em turbilhão \\ com Marian me ajudando \\ com sua voz profunda -- minha Irmã.
}

(SOUSA, 2001, p. 58)

Esse movimento de inclusão se intensifica, no decorrer da poesia, por meio de uma personificação afetiva das massas, do povo, na forma de entes queridos, familiares e amigos. A partir de então, a melancolia do eu lírico e o mal-estar coletivo se perpassam, entrecruzam, pois o grito do povo não é mais o clamor de um ele distante, mas de sujeitos que fazem parte da vida íntima do $e u$ enunciador:

\title{
Escrevo...
}

Na minha mesa, vultos familiares se vêm debruçar.

Minha Mãe de mãos rudes e rosto cansado

e revoltas, dores, humilhações,

tatuando de negro o virgem papel branco.

(SOUSA, 2001, p. 58)

Ressalta-se, nesse sentido, que a seleção lexical do poema é bastante representativa da crítica social e do tom de revolta que a instância autoral deseja atribuir ao poema. Palavras como "Revoltas, dores e humilhações" atribuem a voz do eu-lírico um teor argumentativo, bastante expressivo e intensamente marcado pelo tom político que, como se sabe, constitui a prática de Noémia de Sousa em movimentos sociais moçambicanos. No mesmo patamar, "tatuando de negro" sugere um movimento de luta, marcadamente violento, em que a melancolia do povo negro conduz a uma revolta pela ocupação do espaço "branco". Essa revolta é tanto política quanto artística e almeja ocupar tanto um espaço físico quanto simbólico, cultural. 


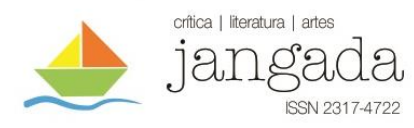

Por fim, ressalta-se que o eu-lírico assume uma posição de militância e de atuação política ferrenha, que objetiva instigar o povo africano a converter seu lamento melancólico em um grito de ação libertária. Evidência desse movimento se dá, intensamente, na última estrofe da poesia, em que o eu-lírico mostra o seu descontentamento pelo lugar ocupado enquanto intelectual e a necessidade de se locomover desse lugar para promover uma arte engajada, em contraposição a uma concepção elitizada de produção artística:

\author{
E enquanto me vierem do Harlem \\ vozes de lamentação \\ e meus vultos familiares me visitarem \\ em longas noites de insônia, \\ não poderei deixar-me embalar pela música fútil \\ das valsas de Strauss. \\ Escreverei, escreverei, \\ com Robeson e Marian gritando comigo:
}

Let my people go,

OH DEIXA PASSAR O MEU POVO.

(SOUSA, 2001, pp. 58-59)

Apesar de sucinta, essa breve leitura do poema de Noémia de Sousa nos foi pertinente para que pudéssemos verificar como a autora constitui em seu texto uma estética melancólica que, ao evidenciar uma angústia coletiva, constitui-se como um grito social e político de libertação. Nesse sentido, de forma distinta ao que verificamos em Florbela Espanca, a poesia de Noémia ultrapassa a questão da melancolia em seu caráter estético e de identificação com o leitor, para localizar-se no patamar de um desconforto que se converte em grito de revolta e, consequentemente, de luta social.

O podemos perceber, a partir de um olhar comparativo com a poética de Florbela Espanca, é que ambos os poemas, observadas as disparidades contextuais e artísticas, utilizam a estética melancólica como um processo propulsor do diálogo entre um eu individual e um outro coletivo - em Espanca, por meio de um pacto com aqueles que fazem parte de um grupo de desafortunados; em Noémia, por meio de um imbricamento 


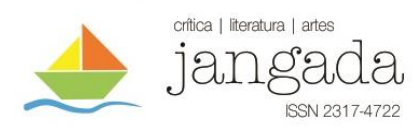

entre as instâncias enunciativas que reverbera na união de autor, leitor e uma terceira pessoa enquanto sujeitos unidos por um ideal social e político em comum.

Na poesia de Ana Cristina Cesar, conforme pretendemos discutir nas próximas páginas, a constituição de uma estética melancólica se dá em um patamar distinto, pois o eu coletivo parece não se constituir como um elemento primordialmente presente no poema selecionado. Nesse sentido, a melancolia se apresenta unicamente como um traço subjetivo, individual, de um indivíduo perdido em sua própria solidão.

\section{A OUTRA FACE DA MOEDA: A FLÂNEUSE MELANCÔLICA}

Desde os primeiros versos, o poema "Cartas de Paris", de Ana Cristina Cesar, já nos apresenta o tom em que será construído, a partir de uma ambientação sensorial na qual a chuva outonal é descrita como "águas mentirosas fecundando campos de melancolia", que suave, carrega as agruras do indivíduo urbano pelas ruas lúgubres de Paris.

Podemos vislumbrar, também, já nesse momento, que a poética da autora pretende entrever outro tipo de dicção melancólica, já evidenciada na antítese entre "fecundação" e "melancolia": O eu lírico de Ana Cristina, ao contrário daquele que conforta os desgraçados, em Florbela Espanca e do que grita pelo povo africano, em Noémia de Sousa, é um sujeito solitário que flana pelo cenário parisiense e, nesse flanar, vivencia a melancolia sobre uma perspectiva individualista, burguesa, baudelairiana.

Nesse sentido, para que possamos analisar a poesia de Ana Cristina Cesar, sobretudo o poema em questão, que estabelece um vínculo intertextual explícito com a obra de Baudelaire, precisamos retomar o conceito de flâneur, conforme apresentado nas discussões de Walter Benjamin:

Uma embriaguez apodera-se daquele que, por um longo tempo, caminha a esmo pelas ruas. A cada passo, o andar adquire um poder crescente; as seduções das lojas, dos bistrôs e das mulheres sorridentes vão diminuindo, cada vez mais irresistível torna-se o magnetismo da próxima esquina, de uma longínqua massa de folhagem, de um nome de rua. [...] Paris criou o tipo do flâneur. [...] Aquela embriaguez anamnésica, na qual o flâneur vagueia pela cidade [...]. (BENJAMIN citado por JACQUES, 2012, p. 55) 
Esse conceito se faz importante, principalmente, pela forma como a autora constrói uma estética da melancolia em seu texto que está diretamente relacionada com a temática da solidão e da errância urbana. Daí a distinção, que procuramos evidenciar na seção anterior, entre os procedimentos estilísticos e temáticos de Ana Cristina e aqueles utilizados por Florbela Espanca e Noémia de Sousa.

Cabe ressaltar, inicialmente, que a poesia de Ana Cristina Cesar é construída de forma epistolar, por meio de um processo de intergenericidade que é uma das características preponderantes da obra da poetisa. Nesse aspecto, Ana Cristina recria ficcionalmente um contexto comunicativo, assim como as duas autoras supracitadas, mas com características que lhe são singulares, sobretudo pelo processo de "mascaramento" que, nesse caso, assume outras perspectivas.

Para exemplificarmos a decorrência do processo de mascaramento e da constituição de uma estética melancólica em Ana Cristina Cesar, recorremos ao seguinte trecho de sua carta-poema:

Eu penso em você, minha filha. Aqui lágrimas fracas, dores mínimas, chuvas outonais apenas esboçando a majestade de um choro de viúva, águas mentirosas fecundando campos de melancolia, tudo isso de repente iluminou minha memória quando cruzei a ponte sobre o Sena. A velha Paris já terminou. As cidades mudam mas meu coração está perdido, e é apenas em delírio que vejo campos de batalha, museus abandonados, barricadas, avenida ocupada por bandeiras, muros com a palavra, palavras de ordem desgarradas; apenas em delírio vejo (CESAR, 1985, p. 283)

Podemos observar, no excerto em questão, que o mascaramento da instância autoral se dá, em Ana Cristina, por meio de dois processos, que, de certa forma, dialogam com a construção do texto das autoras supracitadas: primeiramente, a poetisa lança mão de dêiticos espaciais que fazem referência a Paris como lugar físico e, com isso, criam indexadores textuais que servem como "efeitos de realidade". Estes elementos, ("aqui”, "tudo isso", etc) provocam no leitor a sensação de que há um sujeito real dialogando, em carta, sobre uma experiência vivida concretamente em determinado momento histórico.

Secundariamente, Ana Cristina traz para o texto outros indexadores, mais concretos ainda do que os dêiticos, que tentam, a todo momento, desempenhar um papel 


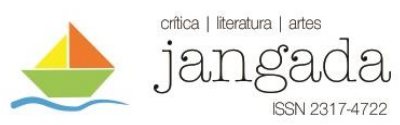

de vínculo com o real. Assim é que surgem trechos como "cruzei a ponte sobre o Sena", "é apenas em delírio que vejo" ou "campos de batalha, museus abandonados, barricadas, avenida ocupada por bandeiras"; que, aliados a uma descrição pormenorizada do espaço parisiense cria um pacto com o leitor e tenta, a todo momento, situá-lo dentro de um contexto comunicativo real.

Além desses dois elementos que, acreditamos, são os mais evidentes, há de se destacar a importância da criação de um interlocutor que seja parte do corpo familiar. Esse terceiro processo, além de colocar em evidência um contexto enunciativo específico, cria uma espécie de vínculo afetivo que traz à tona o caráter intimista e reflexivo das divagações da flâneuse cesariana. Além disso, o processo de identificação com a filha, estabelecido pelo eu-lírico, parece-nos atribuir certa dicção feminina à escrita, que aproximaria ainda mais o sujeito autoral de seu eu-lírico.

De forma sintética, podemos concluir que tais processos de aproximação servem para reafirmar a dicção melancólica presente no texto de Ana Cristina, movimento este que se intensificará no decorrer da carta-poema pelo uso de uma construção sintática assindética que utiliza de elementos metonímicos referenciadores da sensação de tristeza, solidão e abandono - tanto do eu lírico quando do espaço urbano em que transita:

[...] Charles que flana e desespera e volta para casa com frio da manhã e pensa na Força de trabalho que desperta, na fuga da gaiola, na sede no deserto, na dor que toma conta, lama dura, pó, poeira, calor inesperado na cidade, garganta ressecada, talvez bichos que falam, ou exilados com sede que num instante esquecem que esqueceram e escapam do mito estranho e fatal da terra amada, onde há tempestades, e olham de viés [...] (CESAR, 1985, p. 283)

Importante notar, na construção desse trecho, a referência a Baudelaire e ao conceito de flâneur, que servem para destacar uma proposta estética específica da autora e, com isso, estabelecer um vínculo entre o poeta e seu conhecimento enciclopédico e o conteúdo ficcional expresso no interior do poema-carta. Dessa forma, parece-nos evidente que o processo de mascaramento autoral em Ana Cristina Cesar se dá por meio de uma constante aproximação e intromissão textual, sem localizarmos, ao contrário do que 


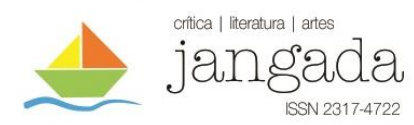

vislumbrávamos nas outras duas autoras, elementos que tentem promover um distanciamento ou algum jogo contrastivo.

No poema-carta de Ana Cristina Cesar, as pessoas da enunciação se aproximam, dialogam afetivamente, compartilhando suas dores e estabelecendo uma espécie de empatia da melancolia. Nesse sentido, perde-se a ideia da coletividade, para vislumbrarmos um sujeito em crise, em conflito, colocado diante de sua própria solidão melancólica.

Ao concluirmos a leitura do poema, no entanto, visualizamos que Ana Cristina também tenta trazer resquícios de uma voz coletiva para as suas lamentações. Os melancólicos da poetisa, no entanto, são se concretizam, são apenas sombras, fantasmas, que em nada dialogam a não ser pelo fato de estarem todos perdidos em sua própria solidão, ou, conforme caracteriza-nos o eu-lírico, por serem "navegantes esquecidos numa balsa, cativos, vencidos, afogados..." - flâneurs e flâneuses de uma Paris que em si é a metonímia de uma melancolia antagonicamente grotesca e sublime.

\section{CONSIDERAÇÕES FINAIS}

A partir das discussões levantadas no presente trabalho, pudemos, de forma sucinta, verificar como essas três importantes poetisas - Florbela Espanca, Ana Cristina Cesar e Noémia de Sousa - apresentam elementos de construção poética que dialogam entre sim, ao constituírem uma poética da melancolia. As singularidades, evidentemente, são bem marcantes, sobretudo pelo contexto histórico e artístico em que emergem cada uma dessas escritoras. No entanto, deve-se ter em vista que muitos elementos são utilizados de forma semelhante, estabelecendo uma espécie de "modelo" de construção da poesia melancólica, cujos traços constituintes tentamos perscrutar.

A respeito das singularidades do processo criativo, destaca-se que, em termos gerais, as autoras estudadas construíram seus poemas por meio de dois processos: 1) o uso de elementos textuais que, de forma mascarada, imerge a instância autoral na voz do eu-lírico, por meio de um jogo de aproximação e de afastamento; 2) a diluição de vozes sociais melancólicas na voz do eu-lírico, promovendo um imbricamento entre um eu individual e um tu coletivo. Em Espanca e Noémia, esse segundo processo se dá de forma mais intensa, revelando posicionamentos pessoais e políticos das autoras de forma mais enfática. Em Ana Cristina, no entanto, a presença das vozes sociais é menor e prevalece 
a inquietação de um sujeito errante, solitário, que caminha pelas ruas de Paris de forma análoga ao flâneur de Baudelaire.

De uma maneira geral, concluímos com a ideia de que uma leitura mais aprofundada sobre os diálogos que se estabelecem entre as obras dessas três autoras apresentaria profícuas referências para uma pesquisa mais abrangente, que focalizasse, inclusive, questões referentes aos traços melancólicos na poesia de autoria feminina, de forma mais abrangente. Existem outras poetisas brasileiras, como Cecília Meireles, que trouxeram à tona processos semelhantes de composição poética - que podem apontar, talvez, para questões relativas ao próprio sistema literário e para o lugar da poetisa na sociedade moderna e pós-moderna.

De nossa parte, tentamos apenas apresentar um breve panorama sobre a estética da melancolia nessas autoras, sem nos atermos, inclusive, a questões mais abrangentes que podem ampliar essa pesquisa de forma bastante produtiva, como, por exemplo, uma análise mais aprofundada da vida das autoras, ou uma leitura psicanalítica da melancolia nas obras aqui estudadas. Assim, finalizamos com o desejo de termos acrescentado uma breve contribuição que aponte para o descortinamento de um debate amplo sobre a escrita dessas três grandes poetisas da literatura produzida em língua portuguesa.

\section{REFERÊNCIAS BIBLIOGRÁFICAS}

BENJAMIN, W. Obras escolhidas. Volume III. Charles Baudelaire: um lírico no auge do capitalismo. São Paulo: Brasiliense, 1989.

BENVENISTE, E. Problemas de Linguística Geral I. 3 ed. São Paulo: Pontes, 1991.

CESAR, A. C. Carta de Paris. Disponível em: http://www.releituras.com/anacesar_menu.asp. Acesso: 24/02/2014.

ESPANCA, F. Este Livro. Disponível em: http://www.citi.pt/cultura/literatura/poesia/florbela_espanca/este_livro.html. Acesso: 24/02/2014.

GOULART, A. T. Tópicos de Literatura Portuguesa: o concurso dos sujeitos no nascimento e no desenvolvimento da literatura portuguesa. Belo Horizonte: PUC-MG, 2012.

HARVEY, D. Condição pós-moderna: uma pesquisa sobre as origens da mudança cultural. São Paulo: Loyola, 1994.

KRISTEVA, J. Sol negro: depressão e melancolia. Rio de Janeiro: Rocco, 1989.

JACQUES, P. B. Elogio aos errantes. Salvador: EDUFBA, 2012. 


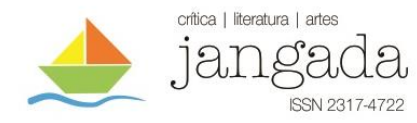

LEJEUNE, P. Definir autobiografia. In MOURÃO, P. (org.). Autobiografia. Autorepresentação. Lisboa: Edições Colibri, 2003.

MORELATO, A. K. S. Entre o passageiro e o eterno: representações da solidão e da melancolia na poesia feminina brasileira. Disponível em: www.cnpq.br/documents/.../6f2780de-463b-4616-94e1-33d2ae353253 . Acesso: 21/10/2013.

PORTO, L. T. Um olhar melancólico: o conto de Caio Fernando Abreu. Disponível em: http://w3.ufsm.br/grpesqla/revista/num6/index01.html. Acesso: 20/10/2013.

SALGUEIRO, W. C. F. Fratura, resistência, paródia: história e estética em três poetas no Brasil Ditatorial. Disponível em: http://w3.ufsm.br/grpesqla/revista/num6/ass03/pag01.html. Acesso: 21/10/2013.

SCLIAR, M. A melancolia na literatura. Cad. Bras. Saúde Mental, Vol. 1, no1, jan.-abr. 2009 (CD-ROM)

SOUSA, N. Deixa passar o meu povo. In: Sangue Negro. Maputo: Associação dos Escritores Moçambicanos, 2001. p. 57-59. 